\title{
Comparative Investigation Of The Effect Of Treatment Methods On Bacterial Population Of Surface Water In Ado Ekiti, Nigeria
}

\author{
Chioma Miracle Ojiako, ${ }^{1,2 *}$, Angus Nnamdi Oli ${ }^{1}$, Jacob 0 Oluyege ${ }^{2}$ and Malachy Chigozie Ugwu ${ }^{1}$ \\ ${ }^{1}$ Department of Pharmaceutical Microbiology and Biotechnology, Nnamdi Azikiwe University, Nigeria \\ ${ }^{2}$ Department of Microbiology, Ekiti State University, Nigeria
}

*Corresponding author: Chioma Miracle Ojiako, Department of Pharmaceutical Microbiology and Biotechnology, Faculty of Pharmaceutical Sciences, Nnamdi Azikiwe University, Awka, Anambra State, Nigeria.

To Cite This Article: Chioma Miracle Ojiako, Comparative Investigation Of The Effect Of Treatment Methods On Bacterial Population Of Surface Water In Ado Ekiti, Nigeria. Am J Biomed Sci \& Res. 2020 - 6(6). AJBSR.MS.ID.001097.

DOI: $10.34297 /$ AJBSR.2020.06.001097

Received: 啙 December 12, 2019 ; Published: 眥 January 16, 2020

\begin{abstract}
Majority of rural populations do not have access to safe water supplies and depend mainly on untreated surface water such as streams, rivers, etc. This usually leads to the emergence of water borne diseases such as typhoid, dysentery, cholera, etc. Traditional methods of water purification in rural areas involve simple and treatments which majorly aim at the visible impurities from the water. Examples include: Boiling, filtration, Sedimentation, Solar disinfection. There is a high need for more effective and affordable water purification techniques in rural areas, in order to prevent water borne diseases. This study investigated the effects of different methods of water sanitation/treatments on the Bacterial population of Surface water (Stream) in Ado Ekiti, Ekiti state country. Raw water samples were collected from a selected stream in Ado Ekiti, Ekiti State country. The water was processed for the determination of bacterial densities and were subsequently subjected to sanitation using natural methods (Solar heating and Moringa oleifera seed extract) and chemical methods (Calcium hypochlorite and Citric acid) as treatment agents, at various concentration (between $0.5 \%$ - 2\%).
\end{abstract}

Solar heating of the water samples was affected for 7 hours $(9 \mathrm{am}-4 \mathrm{pm})$. Total bacterial and coliform counts (TBC and TCC) were determined. Reduction of TBC and TCC were significant when the water samples were treated with calcium hypochlorite, Moringa seed extract and solar heating. The pattern of purification and efficiency of the methods used were calcium hypochlorite (100\%), solar heating (81- 95\%), Moringa oleifera seed extracts (61-99.4\%), and citric acid (56\%) bacterial load reduction. Calcium hypochlorite sanitation method gave the best bacterial load reduction effect .However, the use of natural methods of water sanitation such as solar heating and the addition of Moringa oleifera seed extract may be employed for surface water sanitation especially in rural communities in the absence of chemical agents such as calcium hypochlorite.

Keywords: Water quality; Moringa oleifera; Chemical disinfectants; Microbial contamination; Surface water sanitation; Water borne diseases; Solar disinfection; Coliform; Chlorine

\section{Introduction}

The most important natural resource globally is water and a high priority issue for the quality of human existence is the availability of clean and safe drinking water [1] closely followed by appropriate vaccination coverage [2,3]. Access to safe drinking water can be estimated by the percentage of the population using improved drinking water sources. An improved drinking water source is one that is adequately protected from outside contamination, with fecal matter, by the nature of its construction [4]. About $75 \%$ of rural populations depend mainly on untreated streams, ponds and well water for drinking and daily activities (e.g. food preparations, bathing, laundry, etc.). This is due to inaccessibility to safe and quality treated water supplies. However, in such areas, streams or river-dumping have also been a major means of waste disposal, causing these water sources to become repositories of household wastes, animal manure, human faces and community wastewater. In some settlements, chicken scoop, barnyard or pigsty can be 
found very close to the streams or well water sources, which are mainly used for drinking. The water locked inhabitants along the river Niger delta area of Nigeria, discharge their rectal wastes into waterways, which also serve as their source for drinking and other activities. Some developed countries are not an exception as well. In Southern Asia and Africa, open defecation is widely practiced (44\% and $27 \%$ respectively) [4].

Other sources of pollution could arise from surface run-off from soil erosion, lumbering, dredging, etc, leading to a wide scale contamination of rivers and other surface water sources. These consequently results in high occurrence rates of water borne diseases such as diarrhea, (CORRECT) cholera, dysentery, typhoid fever [1]. Illiteracy, overcrowding, poverty and low health services are factors which greatly contribute to the prevalence of water borne diseases. According to World Health Organization (WHO), 80\% of all diseases globally can be attributed to unsafe water at any time and one-half of the hospital beds in the world are occupied by people with water-related diseases hence, there is need for the purification of water [5]. Water purification can be defined as the removal of impurities contained in water. Methods of purifying water include ultraviolet light (sun), filtration, water softening, reverse osmosis, ultrafiltration, ionizing and power activated carbon treatment. The traditional methods of purifying water in rural areas include simple and rudimentary treatments which majorly target the visible impurities from the water. Examples include: Boiling, filtration, Sedimentation, Solar disinfection, etc. [6].

In developing countries, access to clean water and sanitation are not the norm, thus waterborne infections are common [7]. WHO had maintained that the mortality of water borne diseases exceeds 5 million people per annum? Improving access to safe drinking-water can result in significant benefits to health and economy of a nation. This study therefore focused on the determination of the effectiveness of various water treatment procedures (solar radiation, calcium hypochlorite, citric acid, and Moringa seed extract) on the bacterial density in surface water sources in Ado Ekiti Ekiti State, Nigeria.

\section{Methods}

\section{Cleaning and sanitization of materials used}

All the glass wares used for the work were properly washed with water and detergent, rinsed thoroughly with water and air dried. Sterilization of all glass wares were carried out by wrapping them with aluminum foil and sterilizing in the hot air oven at 160 ${ }^{\circ} \mathrm{C}$ for 2 hours. The distilled water used for dilution was sterilized in an autoclave at $121^{\circ} \mathrm{C}$ for 15 minutes.

\section{Media preparation}

The media used were Nutrient agar (Lab M, England) and the Mac Conkey agar (Lab M, England). The media were prepared according to the manufacturer's instructions. The appropriate quantities of the dehydrated powder were measured in conical flasks and the appropriate quantity of water was added. For Nutrient agar, $2.8 \mathrm{~g}$ was weighed using a measuring scale, and added to $100 \mathrm{ml}$ of water. For Mac Conkey agar, $4.85 \mathrm{~g}$ was weighed and added to $100 \mathrm{ml}$ of water. They were homogenized in a water bath and sterilized in autoclave for $15 \mathrm{mins}$ at $121^{\circ} \mathrm{C}$.

\section{Collection of the water samples}

The water samples were collected from a flowing stream at Adebayo Street, Ado-Ekiti. The water samples were collected using clean and sterile plastic bottle with a fitted cover and transferred immediately into the laboratory. The total bacterial count and the total coliform counts were taken for the raw water sample.

\section{Determination of bacterial density of surface water}

The total plate count was done using the Pour Plate Technique. A $9 \mathrm{ml}$ of clean water was dispensed into ten (10) test tubes each and sterilized in an autoclave at $121^{\circ} \mathrm{C}$ for 15 minutes. With the aid of sterile syringe, $1 \mathrm{ml}$ of the water sample was aseptically added to the $9 \mathrm{ml}$ sterile solution blank to make $10^{-1}$ dilution. Serial dilution was carried out. One $\mathrm{ml}$ was withdrawn from the last dilution aseptically and poured into a sterile petri dish. Sterile, molten nutrient agar (for total plate count) and sterile Mac Conkey agar (for coliform count), which had been cooled to about $45{ }^{\circ} \mathrm{C}$ were then poured into the petri dishes respectively and allowed to set on the bench. The plating was done on duplicates. The plates were then inverted and incubated at $37{ }^{\circ} \mathrm{C}$ for 24 hours. The colonies formed after 24 hours were counted using a Colony Counter. The Microbial Load per sample was calculated by multiplying colony counts with the Dilution Factor. Microbial load was expressed as colony forming units per $\mathrm{ml}(\mathrm{CFU} / \mathrm{ml})$

\section{Determination of the effect of solar heating on the bactericidal density in the water sample}

The water sample was poured into transparent glass containers with fitted covers. They were placed in a black wooden box that has one transparent glass side. The box was placed with the glass bottles facing the radiation from the sun through the transparent side. The temperature was taken with a thermometer, and $1 \mathrm{ml}$ of each of the water samples were taken at various time intervals (9am, $12 \mathrm{pm}, 2 \mathrm{pm}$ and $4 \mathrm{pm}$ ) and analysed for their total bacterial count and total coliform count. The results were recorded.

\section{Determination of the effect of calcium hypochlorite and citric acid on the bacterial density of the water sample}

Calcium hypochlorite and citric acid are both in granular forms. A stock solution of the compound was made by dissolving $10 \mathrm{~g}$ of either the calcium hypochlorite or citric acid in water. A $0.1 \mathrm{ml}$ of the stock solution was added to $100 \mathrm{ml}$ of the sample and mixed properly. From the mixture, $1 \mathrm{ml}$ was taken and poured into a petri dish and a pour plate technique was carried out. This was repeated, and $0.5 \mathrm{ml}, 1.0 \mathrm{ml}, 1.5 \mathrm{ml}, 2.0 \mathrm{ml}$, was taken from the stock solution respectively into $100 \mathrm{ml}$ of the sample. The same procedure was carried out for citric acid. The results were recorded. 


\section{Determination of the effect of Moringa seed extract on the bacterial density of the water sample}

Moringa seeds were harvested, the outer shells were removed, and the seeds were grinded into powdered form. The powder was dissolved in various concentrations into several conical flasks containing $100 \mathrm{ml}$ of sterile water. $0.5 \mathrm{~g}$ of Moringa seed powder was added to the first conical flask of sterile water to make $0.5 \%$ concentration. $1 \mathrm{~g}$ was added to the second flask to make $1 \%$ concentration. This was done up to $2.5 \%$. The solutions were then stored for 24 hours and filtered to yield the Moringa seed extract.

$1 \mathrm{ml}$ from each of the various extract concentrations were added to $100 \mathrm{ml}$ of the water sample and mixed thoroughly. $1 \mathrm{ml}$ is taken from the mixture and poured into sterile petri dishes and the total bacterial count and total coliform count was determined.

\section{Determination of the effect of Moringa seed extract on the turbidity of the water sample}

The effect of the extract on the turbidity was determined by adding $10 \mathrm{~g}$ of the seed powder to $100 \mathrm{ml}$ of sterile water. It was left for a day and then filtered with Whatman filter paper. $10 \mathrm{ml}$ of the filtrate was added to $100 \mathrm{ml}$ of the water sample and shaken together to mix properly. This was left to sediment. The supernatant was collected, and the turbidity was measured and recorded.

\section{Physicochemical analysis}

The physicochemical analysis of the water sample was carried out to determine the following parameters: $\mathrm{pH}$, temperature, conductivity, odour and appearance, hardness, turbidity, acidity, dissolved oxygen.

Determination of pH: Calibration of the $\mathrm{pH}$ meter was done by dipping it into a beaker containing $100 \mathrm{ml}$ of buffer solution (7.0). After which the electrode was removed from the buffer solution and rinsed with sterile water and the $\mathrm{pH}$ of the water sample was read on the meter.

Determination of temperature: The thermometer used was dipped into the water samples and allowed to stay for some time before the reading was taken in ${ }^{\circ} \mathrm{C}$.

Determination of conductivity: A conductivity meter was adjusted with its knob. The water sample was poured inside its cup and then plugged with the thermometer to trace its reading one after the other.

Determination of odour and appearance: Human sense of smelling was used to examine the odour of the sample and the sense of vision was used to examine the physical appearance of the sample.

Determination of hardness: About $0.01 \mathrm{M}$ of EDTA solution was introduced inside a burette and standardized against $0.1 \mathrm{ml} \mathrm{Na-}$ ${ }_{2} \mathrm{CO}_{3}$. Some of the water samples were pipetted into a conical flask and $2 \mathrm{ml}$ of potassium cyanide which acted as a masking agent was added. Also,3 drops of indicator Enchrome black T, was added and the solution was titrated against $0.001 \mathrm{M}$ EDTA standard until the colour changes from wine red to blue. The titre value was recorded.

$$
\text { Hardness }=\frac{\text { titre value }}{\text { volume of sample }} X 100 \%
$$

Determination of turbidity: The turbidity of each water sample was determined using spectrophotometer at a wavelength of $520 \mathrm{~nm}$. The sample was poured into the spectrophotometer after it was standardized. The turbidity value was read off in the spectrophotometer read out device. The unit is NTU (Normal Turbidity Unit).

Determination of dissolved oxygen: This was done with the use of the dissolved oxygen meter. The electrode of the meter was rinsed with distilled water and then immersed into the water samples, one at a time for a period of time. Readings on this meter was recorded for each sample.

\section{Results}

\section{The effect of solar heating on the bactericidal density of the water sample}

The effect of solar heating on bacterial population of the surface water sample is shown in Table 1 . The total bacterial counts and total coliform counts decreased by $81 \%$ and $95 \%$ respectively within 6 hours after exposure to solar radiation. However, an irregular increase was observed in both the total bacterial and coliform counts after storage of a previously exposed sample within 4 hours (EXP 02).

\begin{tabular}{|c|c|c|c|c|c|c|c|c|c|c|}
\hline \multirow{2}{*}{$\begin{array}{l}\text { Time } \\
\text { of } \\
\text { expo- } \\
\text { sure }\end{array}$} & \multicolumn{2}{|c|}{ EXP 01 (Fresh Sample) } & \multicolumn{2}{|c|}{$\begin{array}{c}\text { EXP } 02 \text { (Previous Sam- } \\
\text { ple*) }\end{array}$} & \multicolumn{2}{|c|}{ EXP 03 (Fresh Sample) } & \multicolumn{2}{|c|}{ EXP 04 (Fresh Sample) } & \multicolumn{2}{|c|}{ EXP 05 (Fresh Sample) } \\
\hline & TBC $\left(10^{3}\right)$ & $\operatorname{TCC}\left(10^{3}\right)$ & ТВC $\left(10^{3}\right)$ & $\operatorname{TCC}\left(10^{3}\right)$ & $\begin{array}{c}\text { TBC } \\
\left(10^{3}\right)\end{array}$ & $\operatorname{TCC}\left(10^{3}\right)$ & ТВC $\left(10^{3}\right)$ & $\operatorname{TCC}\left(10^{3}\right)$ & ТВC $\left(10^{3}\right)$ & $\operatorname{TCC}\left(10^{3}\right)$ \\
\hline $9 \mathrm{AM}$ & 4.5 & 0.8 & 6.4 & 2.1 & 2.7 & 1.5 & 5.5 & 0.9 & 9 & 1.1 \\
\hline $\begin{array}{l}12: 00 \\
\text { PM }\end{array}$ & 3.6 & 0.6 & 5.3 & 3.4 & 0.9 & 0.7 & 0.9 & 0.7 & 7.2 & 0.7 \\
\hline $2 \mathrm{PM}$ & 2.8 & 0.4 & 5.7 & 5.7 & 0.6 & 0.3 & 0.8 & 0.4 & 4.1 & 0.6 \\
\hline $4 \mathrm{PM}$ & 1.3 & 0.3 & 7.4 & 0.1 & 0.3 & 0.1 & 0.5 & 0.1 & 2.3 & 0.2 \\
\hline
\end{tabular}


The effect of Moringa oleifera seed extract (Natural disinfectant) on the bacterial population of the surface water sample

\begin{tabular}{|c|c|c|}
\hline Table 2: The effect of Moringa oleifera seed extract on the bacterial population of the surface water sample. & \multicolumn{2}{c|}{ TCC $\left(\mathbf{1 0}^{\mathbf{1}}\right)$} \\
\hline Concentration of Extract & TBC $\left(\mathbf{1 0}^{\mathbf{1}}\right)$ & 1.1 \\
\hline $0.00 \%$ & 10.8 & 0.8 \\
\hline $0.50 \%$ & 2.7 & 0.6 \\
\hline $1.00 \%$ & 1.9 & 0.5 \\
\hline $1.50 \%$ & 1.7 & 0.3 \\
\hline $2.00 \%$ & 1.2 & 0.2 \\
\hline
\end{tabular}

Table 3: The effect of Citric acid and Calcium Hypochlorite (chemical disinfectants) on the bacterial density of surface water.

\begin{tabular}{|c|c|c|c|c|}
\hline \multirow{2}{*}{ Conc. of Disinfectants } & \multicolumn{2}{|c|}{ Citric Acid } & \multicolumn{2}{c|}{ Calcium Hypochlorite } \\
\cline { 2 - 5 } & TBC $\left(\mathbf{1 0}^{\mathbf{1}}\right)$ & TCC (10 $)$ & TBC (10 $)$ & TCC $\left(\mathbf{1 0}^{\mathbf{1}}\right)$ \\
\hline $0.00 \%$ & 10.8 & 9.4 & 0.8 & 9.4 \\
\hline $0.01 \%$ & 9.9 & 6.7 & 0 & 0 \\
\hline $0.05 \%$ & 8.1 & 8 & 0 & 0 \\
\hline $0.10 \%$ & 7.9 & 6.7 & 0 & 0 \\
\hline $0.15 \%$ & 6.3 & 5 & 0 & 0 \\
\hline $0.20 \%$ & 4.6 & 3.9 & 0 & 0 \\
\hline
\end{tabular}

This can be observed in Table 2. The Moringa oleifera seed extract produced a $99.4 \%$ decrease in total bacterial counts and $61 \%$ decrease in the total coliform counts of the water samples. It was observed that the turbidity of the Moringa oleifera treated water, decreased from 3.5 (NTU) to 0.8 (NTU), showing the effectiveness of Moringa oleifera seed extract as a coagulant (Table 3).

The effect of citric acid and calcium hypochlorite (chemical disinfectants) on the bacterial density of surface water

Table 4: Physicochemical analysis of the surface water sample.

\begin{tabular}{|c|c|}
\hline Parameter & Value \\
\hline $\mathrm{pH}$ & 7.2 \\
\hline Electrolyte Conductivity (m/s) & 0.4 \\
\hline Total Dissolved Solid (mg/l) & 78 \\
\hline Total hardness (ppm) & 58 \\
\hline Turbidity (NTU) & 3.5 \\
\hline Appearance & Colourless \\
\hline Odour & Odourless \\
\hline
\end{tabular}

${ }^{*}$ The turbidity of the Moringa oleifera treated water $=0.8$ NTU

\section{Discussion}

Safe drinking water for all is one of the key challenges of the $21^{\text {st }}$ century. Many bacterial diseases are transmitted through water thus microbiological control of drinking water should be the norm everywhere. This study evaluated the effects of water sanitation correct on bacterial load of surface drinking water in Ado Ekiti Nigeria. The results obtained in this study shows that the various
With respect to the use of citric acid and calcium hypochlorite, to disinfect the water samples. It was observed that at $0.2 \%$ concentration of citric acid, bacterial load reduction of only $56 \%$ was observed while calcium hypochlorite produced $100 \%$ reduction on the bacterial load at the same concentration.

\section{Physicochemical analysis of the surface water sample}

The result of the physicochemical analysis of the raw surface water sample can be observed in Table 4. (NTU = Normal Turbidity Unit). 
(in Beirut), 95\% of the faecal coliforms of contaminated water were killed [8]. However, this technique is not suitable during periods of continuous rainfall. A previously conducted research showed that the weak, diffused, and attenuated solar radiation filtering through a heavy cloud on a rainy day, failed to affect any noticeable decrease in either the total bacteria or the coliform content of the stream sample [9].

Bacteria once exposed to solar radiation for a short period of time may likely become more resistant to inactivation. This accounts for the irregular increase seen in Table 1 (EXP 02), using a previously exposed sample). The ineffectiveness of solar energy as a water disinfectant could be due to the under exposure of the water source to the sun rays, which presumably selected the bacteria content for solar resistance. Studies have shown that E. coli is more resistant to the sun than other bacteria (e.g. Pseudomonas aeruginosa, Salmonella enteritidis, Shigella flexneri, Salmonella typhymuri$u m$, etc), making it a suitable indicator of the efficacy of Solar disinfection $[10,11]$. The effectiveness of solar disinfection technique is determined by the quantity of water exposed, the total amount of solar radiation during exposure, the temperature of the water and the total bacterial and coliform count at the beginning and at the end of the experiment [12].

Turbid water significantly decreases the level of solar inactivation of bacteria. Research has shown that bacteria are more rapidly inactivated by solar radiation in clear non- turbid water. Highly turbid water can be filtered to reduce its turbidity before SODIS treatment [13]. Solar decontamination works better when the water sample is exposed in clear transparent glass or plastic containers than in dark, opaque containers. The inactivation of bacteria is increased by the synergy between the temperature and optical irradiance [14]. Although, there are concerns on the use of plastic containers such as their potential to be carcinogenic, glass containers on the other hand have an advantage as they do not suffer the effects of aging, hence can be used for a longer period of time [14].

The results in this study (Table $2 \& 3$ ) shows that the filtrate from the Moringa oleifera seeds have both antimicrobial and coagulating properties and this makes it a useful agent for water treatment especially during rainy seasons when rivers carry highly turbid water [15]. Irrespective of the technology used in the treatment of water, they primarily have to overcome the hurdle of removing the turbidity from the water source. It is a very crucial step towards water treatment. Research has indicated that Moringa oleifera seed extract coagulate $80-90 \%$ turbidity and colour, efficiently leading to a clear supernatant [16]. Similarly, a significant decrease in the turbidity and total coliform content in water samples from shallow wells have also been observed [17].

Apart from the economic drawback, chemical based water treatment agents such as metal salts, synthetic polymers and chlorine formulations are also considered to have a negative impact on both human health and the environment after a long exposure. Naturally occurring alternatives such as the use of Moringa oleifera seed are generally considered safe and has therefore been investigated for decades. One major disadvantage of using Moringa oleifera seed extract is that due to its organic nature a high amount of it can lead to the release of organic matter from its seed into the water. This can cause odour, taste, colour problems [18], and could also enhance the development of microorganisms after a while [19].

The treatment of water by disinfecting it with chlorine-based compounds such as calcium hypochlorite at various concentrations is an effective treatment method, as seen in Table 3. Chlorine is by far, the most commonly used disinfectant and also the only affordable means of disinfecting drinking water in developing countries. It can be added to the water either as liquid or gas [20]. The efficacy of water disinfection with chlorine can be influenced by several factors. These include the $\mathrm{pH}$ and turbidity of the water, the concentration of chlorine and contact time. Turbidity can have negative effects on disinfection because high turbid levels have been shown to protect microorganisms from the action of chlorine, and also to increase the chlorine and oxygen demand [21].

Chlorine (as well as other disinfectants) reacts with certain water constituents to form new compounds with potentially harmful long-term health effects. It reacts with Natural Organic Matter (NOM) to Disinfection By-Products (DBPs). The by-products of Chlorine disinfection have been extremely identified and assessed for toxicity. However, the health risks from these by-products are extremely small in comparison with the risks associated with inadequate disinfection [22]. Research has shown that although citric acid exhibited low toxicity to freshwater fish, daphnia, Algae, and activated sludge microorganisms. It has obvious toxic potential against protozoans and many species or strains of bacteria [23].

Furthermore, this study is clear evidence that citric acid has little or no effect on the total bacteria and coliform content (as seen in Table 3) of the surface water sample. This is indicative of the fact that the use of citric acid as a water treatment agent is purely ineffective compared to the other treatment methods employed in this study.

\section{Conclusion}

The various water treatment methods used in this study are effective procedures for the treatment of surface water in rural areas, the most efficient method being the use of chlorine-based compounds such as calcium hypochlorite, while the least efficient being the use of citric acid. However, before any treatment method could be effective, the turbidity of the water sample should be removed either by the addition of a coagulant or by filtration.

\section{References}

1. Khan Md. ZH, Al Mamum Md R, Majinder SC, Kamruzzan Md (2015) Water purification and disinfection by using solar energy: Towards green energy challenge. Int J Sci Technol 4(3): 99-106. 
2. Oli AN, Agu RU, Ihekwereme CP, Esimone CO (2017) An evaluation of the cold chain technology in South-East, Nigeria using immunogenicity study on the measles vaccines. The Pan African Medical Journal 27 (Supp 3): 28.

3. Oli AN, Agu RU, Oli UC, Nwoye CU, Ejiofor O, et al. (2015) Safety evaluation in mice of the childhood immunization vaccines from two south-eastern states of Nigeria. Asian Pac J Trop Biomed 5(2): 132-137.

4. WHO/UNICEF (2010) A snapshot of Drinking-water and Sanitation in the MDG region sub-Saharan Africa. Update WHO (2011). World Health Statistics.

5. WHO (2006) Guideline for drinking water quality incorporation first addendum. Vol 1. Recommendations for ( $3^{\text {rd }}$ edn).

6. Chaurasia S, Tiwari AK (2015) A review on traditional water purification methods used in Rural Areas. IJEP 36(1): 43-48.

7. Cabral JP (2010) Water Microbiology, Bacterial Pathogens and Water. Int J Environ Res Public health 7(10): 3657-3703.

8. Accra A, Raffoul Z, Karahagopian (1984) Solar disinfection of Drinking water and Oral Rehydration Solutions: Guidelines for household applications in developing countries. UNICEF. Illustrated Publications, S.A.L, Beirut, Lebanon pp.1-56.

9. Odeyemi O (1987) An assessment of Solar disinfection of drinking water in Nigeria. Final Project Report to UNu, Obafemi Awolowo University, IleIfe, Nigeria p. 34.

10. Kehoe SC, Joyce TM, Ibrahim P, Gillespie JB, Shahar RA, et al. (2004) Batch process solar disinfection is an efficient means of disinfecting drinking water contaminated with Shigella dysenteriae type I. Lett Appl Microbiol 38(5): 410-414.

11. Boyle MA, Sichel C, Fernandez-Ibanez P, Arias-Quiroz GB, Iriarte-Puna M, et al. (2008) Identifying the bacterial limits of Solar Disinfection (SODIS) of water under real sunlight conditions. Appl Environ Microbiol 74: 2997-3001.

12. Odeyemi O (1986) Use of Solar Radiation for Water Disinfection. INRESA Secretariat, Brace Research Institute, Ste Anne de Bellevue, Quebec, Canada.
13. Sommer B, Marino A, Solarte M, Dierolf C, Valiente C, et al. (1997) SODISan emerging water treatment process. J Water Supply Res Technol 46(3): 127-137.

14. Asiimwe JK, Quilty B, Muyanja CK, MacGuigan KG (2013) Field comparison of solar water disnfection (SODIS), efficacy between glass and polythene terephalate (PET) plastic bottles under sub-saharan weather conditions. J Water Health 11(4): 4.

15. Muyibi S, Alfugara A (2003) Treatment of surface water with Moringa oleifera seed extract and alum- a comparative study using a pilot scale water treatment plant. International Journal of Environmental studies 60(6): 617-626

16. Delelegn A, Sahile, Husen A (2018) Water purification and antibacterial efficacy of Moringa oleifera Lam. Agric \& Food Secur 7: 25

17. Pitchard M, Mkandawire T, Edmondson T, O Neil JG, Kululanga G (2009) Potential of using plant extracts for purification of shallow well water in Malawi. Phys Chem Earth 34(13-16): 799-805.

18. Ndabigengesere AI, Nasaraiah KS (1996) Influence of operating parameters on turbidity removal by coagulation with Moringaoleifera seeds. Environ Technol 17(10): 1103-1112

19. Oludoro AO, Aderiye BI (2007) Efficacy of Moringa oleifera seed extract on the microflora of surface and underground water. J Plant Sci 2(4): 453-458.

20. Shamrukh M, Hassan Y (2005) Chlorination and optimal chlorine dosage for Nile water. ASCE. Conference Paper.

21. WHO (1996) Guidelines for drinking water quality, ( $2^{\text {nd }}$ edn). World Health Organization, Geneva, Switzerland.

22. WHO (1993) Guidelines for drinking water quality, (1 $1^{\text {st }}$ edn). World Health Organization, Geneva, Switzerland.

23. SIDS (2001) Citric Acid: SIDS Initial Assessment report for $11^{\text {th }}$ SIAM. UNEP Publications. 